Please do not remove this page

RMIT

UNIVERSITY

\title{
Identification of key water quality characteristics affecting the filterability of biologically treated effluent in low-pressure membrane filtration
}

Nguyen, Thang; Fan, Linhua; Harris, John; Roddick, Felicity

https://researchrepository.rmit.edu.au/esploro/outputs/9921857821201341/filesAndLinks?institution=61RMIT_INST\&index=null

Nguyen, T., Fan, L., Harris, J., \& Roddick, F. (2010). Identification of key water quality characteristics affecting the filterability of biologically treated effluent in low-pressure membrane filtration. Water Science and Technology, 62(8), 1914-1921. https://doi.org/10.2166/wst.2010.531

Published Version: https://doi.org/10.2166/wst.2010.531

Repository homepage: https://researchrepository.rmit.edu.au

(C) IWA Publishing 2010

Downloaded On 2023/04/27 01:13:41 +1000 


\title{
Citation:
}

Nguyen, T, Fan, L, Harris, J and Roddick, F 2010, 'Identification of key water quality characteristics affecting the filterability of biologically treated effluent in low-pressure membrane filtration',

Water Science and Technology, vol. 62, no. 8, pp. 1914-1921.

\section{Identification of key water quality characteristics affecting the filterability of biologically treated effluent in low-pressure membrane filtration}

\author{
T. Nguyen, L. Fan, F. A. Roddick*, J.L. Harris \\ School of Civil, Environmental and Chemical Engineering, RMIT University, GPO Box 2476, \\ Melbourne, VIC 3001, Australia. \\ *Corresponding author: Tel: +613 9925 2080, fax: +613 99253746. \\ (E-mail: felicity.roddick@rmit.edu.au)
}

\begin{abstract}
There are many water quality characteristics which could influence the filterability of biologically treated effluent from Melbourne's Western Treatment Plant (WTP). Statistical correlation was used to identify the key water characteristics affecting the microfiltration (MF) and ultrafiltration (UF) filterability in terms of permeate volume of the treated effluent. The models developed showed that turbidity, dissolved organic carbon (DOC) and total suspended solids (TSS) were the key factors which influenced the MF and UF filterability. Turbidity was the dominant factor affecting the accuracy of the model for MF filterability while DOC was the major factor affecting the accuracy of the model for UF filterability. A prediction accuracy of $85 \%$ was obtained for MF and $86 \%$ for UF filterability of the WTP effluent. The characteristics of the organic components of the wastewater were demonstrated by EEM spectra to have seasonal variation which would have reduced the prediction accuracy. As turbidity, DOC and TSS can be determined on-line, the models would be useful for rapid prediction of the filterability of WTP effluent and this may assist the control of low-pressure membrane filtration processes.
\end{abstract}

Keywords: Biologically treated effluent; low-pressure membrane filtration; filterability; statistical correlation

\section{INTRODUCTION}

Western Treatment Plant (WTP) treats approximately 52\% of Melbourne's sewage using a combined activated sludge-lagoon treatment (AS-lagoon) process run as two parallel systems (25W and 55E). The sewage first passes through activated sludge ponds with anoxic and aeration zones where biodegradable matter is consumed by naturally-occurring bacteria. The biologically treated effluent then passes through a clarifier and a chain of lagoons before it goes to the Head of the Road Storage pond (HORS) where it is released as Class $\mathrm{C}$ recycled water without disinfection or as Class A recycled water after disinfection. The recycled water is currently used for various on-site and offsite purposes, however, due to catchment issues such as industrial waste input and saline aquifer infiltration, its salt content limits its long term sustainable use for some applications, such as agriculture, without additional treatment (Melbourne Water, 2005). Pilot-scale membrane salt reduction trials at WTP, which utilised microfiltration (MF) or ultrafiltration (UF) as a pretreatment prior to reverse osmosis, have demonstrated that the product water from this process is suitable for various applications including agriculture and domestic use.

Particles, colloids, salts, organic matter, algae and soluble microbial products (SMP) derived from biological wastewater treatment processes can adsorb and deposit on the membrane surface, and result in fouling. Membrane fouling leads to a decline in membrane permeability and thus reduces throughput and water recovery. Fouling in low-pressure membrane filtration of biologically treated effluent can be due to effluent organic matter (EfOM) (Shon et al., 2006), inorganic (Zularisam et al., 2006), colloidal (Schäfer et al., 2000) and biological matter (Kimura et al., 2004) in the feed water. Algal organic matter (AOM) derived from blue green algae (Lee et al., 2006) and extracellular organic matter (EOM) released from algae (Babel et al., 2002) also contribute to fouling in low-pressure membrane filtration. Fouling due to organic and inorganic components can occur simultaneously, and the components may interact in terms of mechanism (Amjad, 1992). Low-pressure membrane fouling mechanisms are not only a function of membrane type (MF or UF) 
but also depend on feed water characteristics (Lee et al., 2004). Therefore the overall fouling process of MF and UF membranes used for pretreatment of biologically treated effluent is complex and difficult to predict.

The aim of this work was to determine if the MF and UF filterability (measured in terms of permeate volume collected at a final flux of $40 \mathrm{~L} \mathrm{~m}^{-2} \mathrm{~h}^{-1}$ ) of the treated effluent from WTP could be modelled by a simple mathematical relationship in terms of turbidity, total suspended solids (TSS), total dissolved solids (TDS), algal count, dissolved organic carbon (DOC) and conductivity. This could be used to identify the relative importance of these parameters in influencing the fouling propensity of the secondary effluent in low-pressure membrane filtration.

\section{METHODOLOGY \\ Effluent samples}

Samples of biologically treated effluent prior to disinfection were collected monthly from the storage pond (HORS) at WTP over Mar 07-Sept 08. Two series of samples were collected at different times each month: the first series was used for the development of models, while the second series, which was collected separately over the sampling period, was employed to determine the prediction accuracy of the models. HORS samples were stored at $4^{\circ} \mathrm{C}$ and tested as soon as possible after collection. Samples were warmed to room temperature $\left(22 \pm 1^{\circ} \mathrm{C}\right)$ immediately before MF and UF experiments. The samples were filtered $(0.45 \mu \mathrm{m})$ prior to the measurement of DOC and fluorescence analysis.

\section{Microfiltration and ultrafiltration experiments}

The MF and UF filterability of HORS samples was determined using a bench-scale dead-end stirred cell rig (Amicon 8050, effective membrane area $13.4 \mathrm{~cm}^{2}$ ) which was connected to a feed reservoir and operated at a constant pressure regulated using nitrogen gas at $70 \mathrm{kPa}(\mathrm{MF})$ or $110 \mathrm{kPa}(\mathrm{UF})$ and stirrer speed of $430 \mathrm{rpm}$. The permeate flux was determined using a top-loading electronic balance (BP6100, Sartorius, accuracy $\pm 0.1 \mathrm{~g}$ ) connected to a computer for continuous data logging. Hydrophilic polyvinylidene fluoride (PDVF) membranes (Durapore GVWP $0.22 \mu \mathrm{m}$ ) were used for MF and hydrophilic polyethersulphone (PES) membranes (Amicon PBKHK $100 \mathrm{kDa}$ ) were used for UF tests. Only those membranes for which the pure water flux $\left(\mathrm{J}_{\mathrm{o}}\right)$ was in the range of $3269 \pm 179 \mathrm{~L}$ $\mathrm{m}^{-2} \mathrm{~h}^{-1}$ (MF) or $1567 \pm 90 \mathrm{~L} \mathrm{~m}^{-2} \mathrm{~h}^{-1}$ (UF) were used for the filterability tests. As noted above, a benchmark for filterability of permeate volume collected at a final flux of $40 \mathrm{~L} \mathrm{~m}^{-2} \mathrm{~h}^{-1}$ was used.

\section{Analytical methods}

Turbidity was measured at room temperature $\left(21 \pm 1^{\circ} \mathrm{C}\right)$ as Formazin Attenuation Units (FAU) using a Hach DR 4000 spectrophotometer. DOC was determined using a Sievers 820 TOC analyser. Other water quality parameters such as conductivity, TDS, TSS and algal count were routinely measured by Ecowise Environmental (Victoria) Pty Ltd. Excitation-emission matrix (EEM) analysis of water samples was carried out using a Perkin Elmer Luminescence Spectrometer LS50B.

\section{Statistical methods}

Standard variation (SVAR), defined in the same manner as standard deviation, provides a measure of variability which reflects the difference between the measurements and the average measurement. The SVAR for $n$ measurements is expressed as:

$$
S V A R=\sqrt{\frac{\sum\left(x_{i}-x_{A V G}\right)^{2}}{(n-1)}}
$$


Relative variation (RVAR) is the ratio of the standard variation to the average value and given as percent:

$$
R V A R(\%)=\left(\frac{S V A R}{x_{A V G}}\right) \times 100
$$

Multiple linear regression (MLR) models were developed using MiniTab 15 statistical software and experimental data from the first series of samples. The accuracy of the model for the second series of samples was determined by examining the agreement between the experimental values and the values calculated from the model. The accuracy of a MLR model for predicting the filterability of WTP effluent is defined as:

$$
\operatorname{Accuracy}(\%)=\left[1-\left(\frac{1}{n} \sum \frac{\left|V_{\text {experimental }}-V_{\text {predicted }}\right|}{V_{\text {experimental }}}\right)\right] \times 100
$$

where $\left|V_{\text {experimental }}-V_{\text {predicted }}\right|$ is the absolute value of $\left(V_{\text {experimental }}-V_{\text {predicted }}\right)$.

\section{RESULTS AND DISCUSSION}

\section{Variation of water quality characteristics and MF and UF filterability}

The seasonal variation of water quality parameters and MF and UF filterability of HORS water over the sampling period is shown in Table 1. An example of seasonal variation of turbidity, TSS and DOC is shown in Figure 1. The RVAR values for turbidity, algal count and TSS were high compared with those for DOC, TDS and conductivity. The large variability of algal count may be attributed to seasonal change over the sampling period which also contributed to the large variation in turbidity and TSS levels. The effect of seasonal change was less significant for DOC, TDS and conductivity than for algal count, turbidity and TSS. The variability for MF and UF filterability were similar.

Table 1. Seasonal variation of water quality parameters, MF and UF filterability for the first series of HORS

\begin{tabular}{|c|c|c|}
\hline Parameter & Range & RVAR (\%) \\
\hline Turbidity (FAU) & $1-8$ & 51 \\
\hline $\operatorname{TSS}\left(\mathrm{mg} \mathrm{L}^{-1}\right)$ & $2-11$ & 39 \\
\hline Algal count (cells $\mathrm{mL}^{-1}$ ) & $650-31,860$ & 77 \\
\hline $\operatorname{DOC}\left(\mathrm{mg} \mathrm{L}^{-1}\right)$ & $9.3-11.6$ & 9 \\
\hline $\operatorname{TDS}\left(\mathrm{mg} \mathrm{L}^{-1}\right)$ & $870-1200$ & 8 \\
\hline Conductivity $\left(\mu \mathrm{S} \mathrm{cm}^{-1}\right)$ & $1,700-2,100$ & 5 \\
\hline MF filterability $\left(\mathrm{L} \mathrm{m}^{-2}\right.$ at $40 \mathrm{~L} \mathrm{~m}^{-2} \mathrm{~h}^{-1}$ ) & $348-1,001$ & 33 \\
\hline UF filterability $\left(\mathrm{L} \mathrm{m}^{-2}\right.$ at $\left.40 \mathrm{~L} \mathrm{~m}^{-2} \mathrm{~h}^{-1}\right)$ & $197-555$ & 32 \\
\hline
\end{tabular}
samples. 

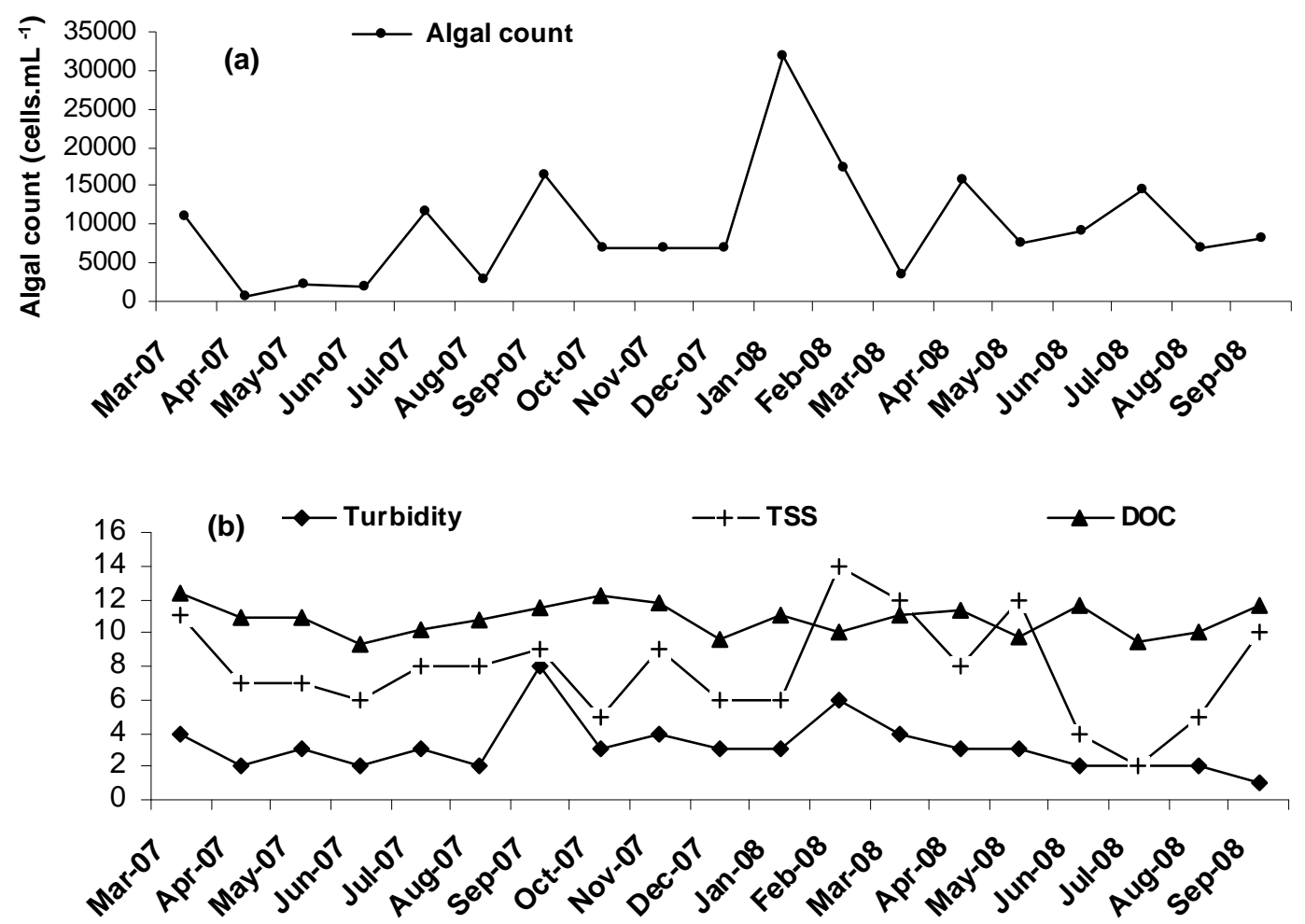

Figure 1. Variation of (a) algal count and (b) turbidity, TSS and DOC of HORS water. (In Figure 1b, units for turbidity are FAU and the units for TSS and DOC are $\mathrm{mg} \mathrm{L}^{-1}$.)

\section{Multiple linear regression (MLR) model for MF filterability}

As a first step in the development of a MLR model for MF filterability, all water quality parameters: turbidity, DOC, TSS, TDS, conductivity and algal count, were included. The correlation between water quality parameters and MF filterability of HORS water was:

where:

$$
V_{M}=1603-54.3 \mathrm{~T}-48.6 \mathrm{O}-4.5 \mathrm{~S}-0.278 \mathrm{D}-0.008 \mathrm{C}-0.65 \mathrm{~A}
$$

- $\mathrm{V}_{\mathrm{M}}=\mathrm{MF}$ permeate volume $\left(\mathrm{L} \mathrm{m}^{-2}\right)$

- $\mathrm{T}=$ Turbidity (FAU)

- $\mathrm{O}=$ Dissolved organic carbon, DOC $\left(\mathrm{mg} \mathrm{L}^{-1}\right)$

- $\mathrm{S}=$ Total suspended solids, TSS $\left(\mathrm{mg} \mathrm{L}^{-1}\right)$

- $\mathrm{D}=$ Total dissolved solids, TDS $\left(\mathrm{mg} \mathrm{L}^{-1}\right)$

- $\mathrm{C}=$ Conductivity $\left(\mu \mathrm{S} \mathrm{cm}^{-1}\right)$

- $\mathrm{A}=$ Algal count $\left(10^{3}\right.$ cells $\left.\mathrm{mL}^{-1}\right)$

The prediction accuracy of this model was evaluated using the second series of 12 samples which were not employed in the development of the model. The agreement between the experimental and the predicted values calculated from Model 1 was $84.9 \%$. To study the effect of each water quality characteristic on the accuracy of Model 1, each variable was removed one at a time so that a new model was established and the effect of this variable on the accuracy of the subsequent model was determined. The model for MF filterability of HORS water with highest accuracy was: 


$$
\mathrm{V}_{\mathrm{M}}=1673-56.7 \mathrm{~T}-49.3 \mathrm{O}-4.1 \mathrm{~S}-0.192 \mathrm{C}-0.39 \mathrm{~A}
$$

As shown in Table 2, conductivity (C), algal count (A) and TDS (D) can be omitted from Model 1 with very little change in the prediction accuracy. Therefore, a suitable model for prediction of MF filterability of HORS water was:

$$
V_{M}=1391-58.8 T-57 O-5.3 S
$$

Omission of TSS (S) in addition to algal count, conductivity and TDS (D) led to only a minor reduction in prediction accuracy of Model 1 from $84.9 \%$ to $83.9 \%$, and the removal of all parameters except turbidity $(\mathrm{T})$ reduced the accuracy of Model 1 to $82.3 \%$.

\begin{tabular}{|c|c|c|}
\hline MLR model & $\begin{array}{l}\text { Parameters not } \\
\text { included in model }\end{array}$ & $\begin{array}{c}\text { Accuracy of } \\
\text { model }(\%)\end{array}$ \\
\hline $\begin{array}{l}V_{M}=1603-54.3 T-48.6 \mathrm{O}-4.5 \mathrm{~S}-0.278 \mathrm{D}-0.008 \mathrm{C}- \\
0.65 \mathrm{~A}\end{array}$ & none & 84.9 \\
\hline $\mathrm{V}_{\mathrm{M}}=1607-55.7 \mathrm{~T}-48.6 \mathrm{O}-4.2 \mathrm{~S}-0.268 \mathrm{D}-0.019 \mathrm{C}$ & A & 85.0 \\
\hline $\mathrm{V}_{\mathrm{M}}=1597-54.2 \mathrm{~T}-48.7 \mathrm{O}-4.6 \mathrm{~S}-0.286 \mathrm{D}-0.66 \mathrm{~A}$ & $\mathrm{C}$ & 84.9 \\
\hline$V_{M}=1673-56.7 T-49.3 \mathrm{O}-4.1 \mathrm{~S}-0.192 \mathrm{C}-0.39 \mathrm{~A}$ & $\mathrm{D}$ & 85.1 \\
\hline$V_{M}=1632-58.8 \mathrm{~T}-48.6 \mathrm{O}-0.260 \mathrm{D}-0.046 \mathrm{C}-0.28 \mathrm{~A}$ & $\mathrm{~S}$ & 84.0 \\
\hline$V_{M}=1395-56.1 \mathrm{~T}-4.5 \mathrm{~S}-0.315 \mathrm{D}-0.146 \mathrm{C}-0.68 \mathrm{~A}$ & $\mathrm{O}$ & 83.5 \\
\hline$V_{M}=1651-52.9 \mathrm{O}-17.8 \mathrm{~S}-0.556 \mathrm{D}+0.129 \mathrm{C}-4.67 \mathrm{~A}$ & $\mathrm{~T}$ & 79.7 \\
\hline$V_{M}=1391-58.8 T-57 O-5.3 \mathrm{~S}$ & $\mathrm{~A}, \mathrm{C}, \mathrm{D}$ & 84.8 \\
\hline $\mathrm{V}_{\mathrm{M}}=1377-63.6 \mathrm{~T}-58.1 \mathrm{O}$ & $A, C, D, S$ & 83.9 \\
\hline $\mathrm{V}_{\mathrm{M}}=800-63.2 . \mathrm{T}-6.7 \mathrm{~S}$ & A, C, D, O & 82.6 \\
\hline$V_{M}=767-69.5 T$ & $\mathrm{~A}, \mathrm{C}, \mathrm{D}, \mathrm{O}, \mathrm{S}$ & 82.3 \\
\hline
\end{tabular}

Table 2. Effect of quality parameters on the accuracy of the MLR models for MF filterability.

\section{Multiple linear regression model for UF filterability}

For UF, the MLR model for HORS water with highest prediction accuracy was:

$$
\mathrm{V}_{\mathrm{U}}=1505-70.3 \mathrm{O}-13.8 \mathrm{~S}-14.6 \mathrm{~T}-0.115 \mathrm{C}-1.57 \mathrm{~A}
$$

The effect of each water quality characteristic on the prediction accuracy of Model 4 is shown in Table 3. There was little change in the prediction accuracy of Model 4 when algal count (A), conductivity (C) and TDS (D) were removed, therefore a suitable model for the UF filterability of HORS water was:

$$
V_{U}=1328-75.1 \mathrm{O}-18.6 \mathrm{~T}-13.8 \mathrm{~S}
$$

Omission of all parameters but DOC $(\mathrm{O})$ from Model 4 changed the accuracy of this model from $85.1 \%$ to $79.8 \%$.

As shown in Model 3 for MF filterability and Model 5 for UF filterability, turbidity, DOC and TSS were the key factors affecting the MF and UF filterability of HORS water. The extent of the influence of these water quality parameters on the accuracy of the models was different. Turbidity was the dominant factor affecting the accuracy of the MLR model for MF, and DOC was the major factor affecting the accuracy of the model for UF (Tables 2 and 3). As turbidity, DOC and TSS can 
be determined on-line (van den Broeke et al., 2006), Model 3 and Model 5 would be useful for rapid prediction of the MF and UF filterability, respectively, of HORS water.

Table 3. Effect of quality parameters on the accuracy of the MLR models for UF filterability.

\begin{tabular}{ccc}
\hline \multicolumn{1}{c}{ MLR model } & $\begin{array}{c}\text { Parameter not } \\
\text { included in model }\end{array}$ & $\begin{array}{c}\text { Accuracy of } \\
\text { model (\%) }\end{array}$ \\
\hline $\mathrm{V}_{\mathrm{U}}=1472-69.9 \mathrm{O}-14 \mathrm{~S}-13.5 \mathrm{~T}-0.128 \mathrm{D}-0.031 \mathrm{C}-1.69 \mathrm{~A}$ & none & 86.1 \\
$\mathrm{~V}_{\mathrm{U}}=1483-70 \mathrm{O}-13 \mathrm{~S}-17.1 \mathrm{~T}-0.101 \mathrm{D}-0.057 \mathrm{C}$ & $\mathrm{A}$ & 86.4 \\
$\mathrm{~V}_{\mathrm{U}}=1447-70.3 \mathrm{O}-14.2 \mathrm{~S}-13.3 \mathrm{~T}-0.155 \mathrm{D}-1.73 \mathrm{~A}$ & $\mathrm{C}$ & 85.7 \\
$\mathrm{~V}_{\mathrm{U}}=\mathbf{1 5 0 5}-\mathbf{7 0 . 3} \mathbf{\mathbf { O }}-\mathbf{1 3 . 8} \mathrm{S}-\mathbf{1 4 . 6} \mathbf{T}-\mathbf{0 . 1 1 5} \mathbf{C}-\mathbf{1 . 5 7 ~ A}$ & $\mathrm{D}$ & 86.7 \\
$\mathrm{~V}_{\mathrm{U}}=1561-69.9 \mathrm{O}-27.4 \mathrm{~T}-0.072 \mathrm{D}-0.146 \mathrm{C}-0.53 \mathrm{~A}$ & $\mathrm{~S}$ & 85.4 \\
$\mathrm{~V}_{\mathrm{U}}=1172-14 \mathrm{~S}-16.1 \mathrm{~T}-0.181 \mathrm{D}-0.23 \mathrm{C}-1.73 \mathrm{~A}$ & $\mathrm{O}$ & 77.2 \\
$\mathrm{~V}_{\mathrm{U}}=1484-71 \mathrm{O}-17.3 \mathrm{~S}-0.197 \mathrm{D}+0.003 \mathrm{C}-2.69 \mathrm{~A}$ & $\mathrm{~T}$ & 83.5 \\
$\mathrm{~V}_{\mathrm{U}}=\mathbf{1 3 2 8}-\mathbf{7 5 . 1} \mathbf{O}-\mathbf{1 8 . 6} \mathbf{T}-\mathbf{1 3 . 8} \mathrm{S}$ & A, C, D & 86.4 \\
$\mathrm{~V}_{\mathrm{U}}=1341-78.3 \mathrm{O}-18.5 \mathrm{~S}$ & A, C, D, T & 83.7 \\
$\mathrm{~V}_{\mathrm{U}}=1291-78 \mathrm{O}-31.2 \mathrm{~T}$ & A, C, D, S & 84.1 \\
$\mathrm{~V}_{\mathrm{U}}=1292-87.2 \mathrm{O}$ & A, C, D, T, S & 79.8 \\
\hline
\end{tabular}

\section{Trends for MF and UF filterability}

Comparisons of the experimental and predicted values calculated from Models 3 and 5 for the filterability of the second series of samples of HORS water (which was not used for the development of the models) are shown in Figure 2. For most samples, the predicted values for MF filterability were higher than the experimental values, except for sample 4 which had an experimental value significantly higher than the predicted value (Figure 2a). The predicted and experimental values for UF filterability were fairly similar, except for samples 7 and 9 for which the predicted values were considerably higher (Figure 2b). The differences between the experimental and the predicted values in Figures 2 may be due to the MF and UF filterability of the HORS water being not only influenced by basic water quality parameters such as turbidity, DOC and TSS as shown by the developed models, but also by other factors such as the presence of supra-colloidal particles in the feed water (te Poele et al., 2004; Soffer et al., 2004), variation of the organic components in the feed water, and the chemical and physical interactions of organic components and the MF and UF membranes (Hong and Elimelech, 1997). These factors, which were not included in the development of the models, would affect the prediction accuracy of the models for MF and UF filterability. The effect of these factors on the accuracy of the developed models requires further investigation.

It should be noted that fresh membranes were used for each filterability test which meant that the influence of biofouling was not investigated in this study. The effect of biofouling on the accuracy and applicability of the models should be considered in longer term trials at pilot-scale. 

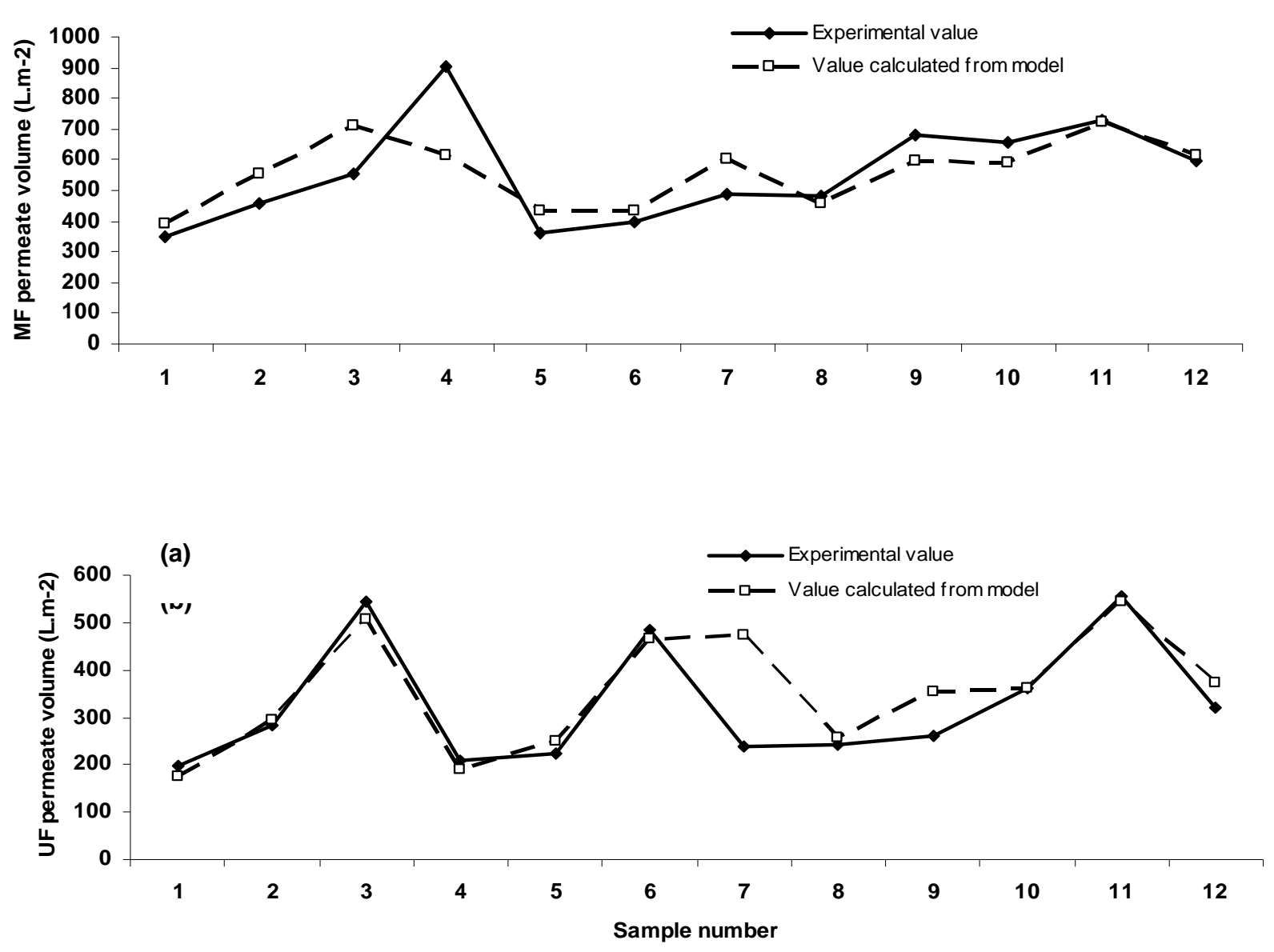

Figure 2. The trends for the experimental and predicted results for (a) MF and (b) UF filterability of HORS water.

\section{Characterisation of the fluorescent organic components}

Both MF and UF models show that DOC had a strong effect on the filterability of HORS samples. Excitation and emission matrices (EEMs) obtained by fluorescence spectroscopy were employed to characterise the dissolved organic compounds in the feed water. EEM spectra were divided into five regions: regions I and II contain peaks at shorter excitation and emission wavelengths $(\mathrm{Ex} / \mathrm{Em}=$ 260/330 nm) which are related to simple aromatic proteins (Determann et al., 1994). Region III comprises peaks $(E x / E m=260 / 380 \mathrm{~nm})$ which are associated with fulvic-like materials (Nguyen et al., 2005). Region IV consists of peaks $(\mathrm{Ex} / \mathrm{Em}=260-340 \mathrm{~nm} / 380 \mathrm{~nm})$ which are related to soluble microbial products (SMPs) (Sheng and Yu, 2006). Region V includes peaks $(E x / E m=260 / 380 \mathrm{~nm})$ which are associated with humic-like organics (Mounier at al., 1999).

The fluorescent component content of samples with similar DOC levels but collected on different dates can differ markedly (Figure 3). For example, samples collected in Dec 07 and July 08 had similar DOC levels of 9.6 and $9.5 \mathrm{mgL}^{-1}$, respectively. The EEM spectra show that the Dec 07 sample contained more proteins (regions I and II), fulvic-like substances (region III), SMPs (region IV) and humic-like materials (region V) than the July 08 sample (Figure 3a). The differences in fluorescent component content of these samples are also illustrated in the regional volumes for the organic components, which were calculated according to the method proposed by Chen et al. (2003) (Table 4). The Dec 07 sample, which had higher regional volumes for proteins, SMP, fulvic- and 
humic-like materials than the July 08 sample, had lower MF and UF filterability. The results obtained for the Feb 08 and Aug 08 samples showed a similar trend (Figure 3b).

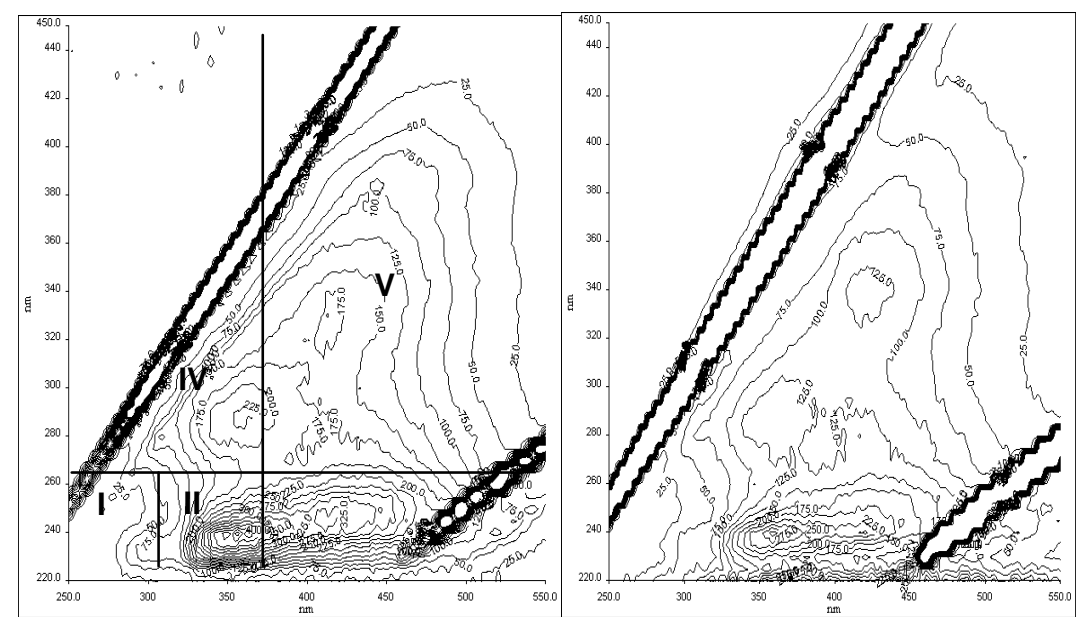

(a)

HORS - Dec 07

HORS - July 08
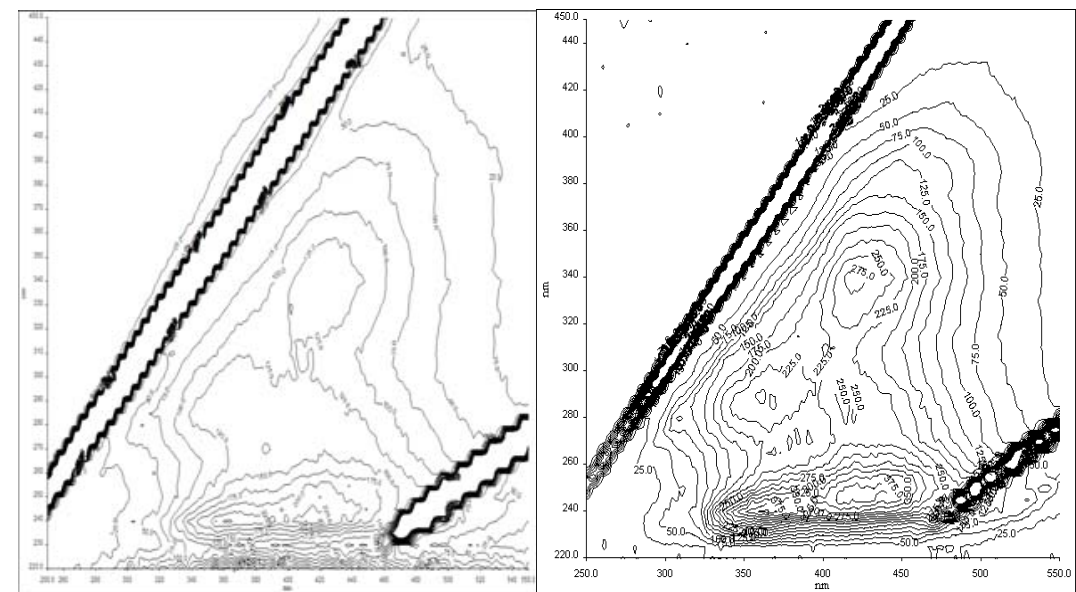

(b)

HORS - Feb 08

HORS - Aug 08

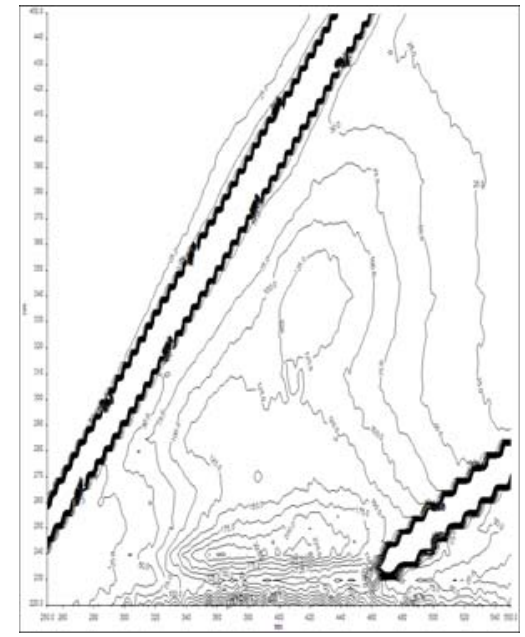

HORS - Feb 08

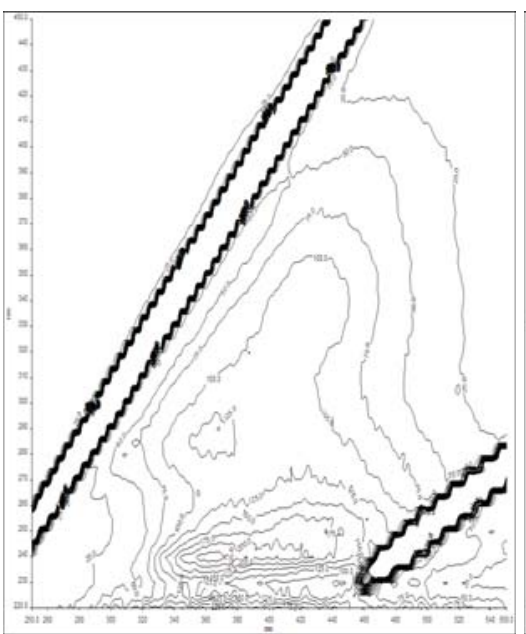

(c)

$25 \mathrm{~W}-\mathrm{Feb} 08$

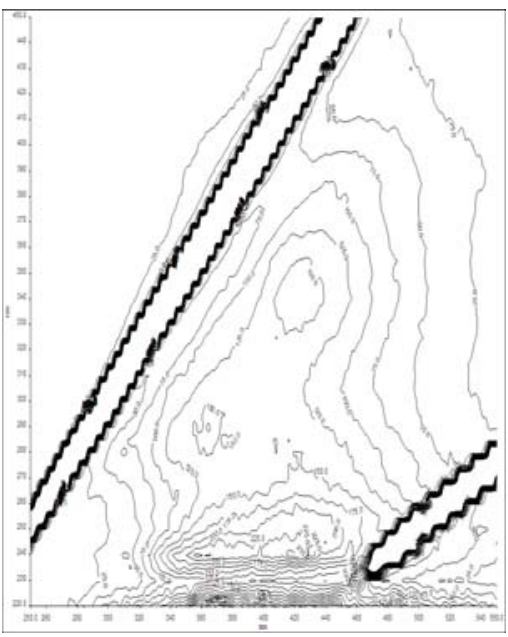

$55 \mathrm{E}-$ Feb 08

Figure 3. EEM spectra (contour maps) of HORS samples which had similar DOC levels (a,b); and HORS, 25W and 55E samples when water ratio in HORS of $25 \mathrm{~W}$ and 55E was 2:3, respectively(c). 
Table 4. Quantification of fluorescent organic components of selected HORS samples of similar DOC level collected over sampling period.

\begin{tabular}{lcccc}
\hline & Dec-07 & July-08 & Feb-08 & Aug-08 \\
\hline DOC $\left(\mathrm{mg} \mathrm{L}^{-1}\right)$ & 9.6 & 9.5 & 10.0 & 10.1 \\
$\begin{array}{l}\text { Volume }\left(\Phi_{i}\right) \text { for Protein (Region I + Region II) } \\
\left(\times 10^{5} \mathrm{AU}-\mathrm{nm}^{2}\right)\end{array}$ & 13.6 & 1.6 & 10.4 & 0.6 \\
$\begin{array}{l}\text { Volume }\left(\Phi_{i}\right) \text { for SMPs } \\
(\text { Region IV) }\end{array}$ & 29.6 & 3.5 & 25.5 & 1.2 \\
$\left(\times 10^{5} \mathrm{AU}-\mathrm{nm}^{2}\right)$ & & & \\
$\begin{array}{l}\text { Volume }\left(\Phi_{i}\right) \text { for fulvic-like materials (Region III) } \\
\left(\times 10^{5} \mathrm{AU}-\mathrm{nm}^{2}\right)\end{array}$ & 56.3 & 6.6 & 48.1 & 2.5 \\
$\begin{array}{l}\text { Volume }\left(\Phi_{i}\right) \text { for humic-like materials ( Region V) } \\
\left(\times 10^{5} \mathrm{AU}-\mathrm{nm}^{2}\right)\end{array}$ & 101.6 & 11.6 & 85.3 & 4.4 \\
$\begin{array}{l}\text { MF permeate volume } \\
\left(\mathrm{L} \mathrm{m}^{-2}\right)\end{array}$ & 539 & 731 & 396 & 1001 \\
$\begin{array}{l}\text { UF permeate volume } \\
\left(\mathrm{L} \mathrm{m}^{-2}\right)\end{array}$ & 484 & 555 & 216 & 499 \\
\hline
\end{tabular}

A previous study by Nguyen et al. (2009) showed that humic-like materials, SMPs, and protein-like extracellular matter were prominent in the fouling layer of the fouled MF and UF membranes used for low-pressure membrane filtration of biologically treated effluent. Therefore, the difference in MF and UF filterability of the samples having similar DOC levels could be due to the differences in humic-like materials, SMPs, and protein-like extracellular matter between these samples and this would affect the prediction accuracy of the models when these samples were used for the development of the models.

HORS water comprised varying proportions of treated water from the $25 \mathrm{~W}$ and $55 \mathrm{E}$ systems depending on operational issues such as turbidity, ammonia concentration and algal blooms. For example, the HORS sample collected in February 08 comprised 25W and 55E water at a ratio of 2:3. EEM spectra show that there was marked difference in the organic components between HORS, $25 \mathrm{~W}$ and $55 \mathrm{E}$ water (Figure 3c). HORS water contained more protein (region II), fulvic-like substances (region III), SMPs (region IV) and humic-like materials (region V) than $25 \mathrm{~W}$, but less than that of 55E. The variation in the organic content in HORS and its source lagoons would explain some of the difficulty in establishing models to predict the MF and UF filterability of HORS water. The predictability of the model may be better for more uniform wastewater.

\section{CONCLUSION}

Statistical correlations between the water quality parameters and the MF and UF filterability showed that turbidity, DOC and TSS were the dominant factors affecting the MF and UF filterability of the WTP effluent. As turbidity, DOC and TSS can be determined on-line, the models could be used for rapid prediction of the MF and UF filterability of the effluent with an accuracy of $85 \%$ and $86 \%$, respectively; thus there is potential for using the models for process control in low-pressure membrane filtration of the effluent from WTP. The accuracy of the model for MF filterability was only marginally reduced when algal count, conductivity, TDS, dissolved organic carbon and TSS were omitted, ie., it depended only on turbidity. It was shown that algal count, conductivity, TDS and TSS can be removed from the model for UF filterability to give only marginally less accuracy. The models show that turbidity was the dominant factor affecting the accuracy of the model for MF filterability, while DOC was the major factor affecting the accuracy of the model for UF filterability. 
The numerical models developed in this paper would not be directly applicable to other biologically treated water sources, but the methodology is applicable and the key water parameters affecting filterability are likely to be relevant. The applicability of the models to pilot-scale using various water sources and membrane materials needs further investigation.

\section{ACKNOWLEDGEMENT}

This research was funded by Smart Water Fund Victoria, Australia (Project number 32M-2076V2)

\section{REFERENCES}

Amjad Z. (Ed.). Reverse Osmosis, Membrane Technology, Water Chemistry and Industrial Application. Van Nostrand Reinhold, New York, 1992.

Babel S., Takizawa S. and Ozaki H. (2002). Factors affecting seasonal variation of membrane filtration caused by Chlorella algae. Water Research, 36, 1193-1202.

Chen, W., Westerhoff, P., Leenheer, J. A. and Booksh, K. (2003). Fluorescence excitation-emission matrix regional integration to quantify spectra for dissolved organic matter. Environmental Science and Technology, 37, 5701-5710.

Determann S., Reuter R., Wagner P., and Willkomm R., (1994). Fluorescent matter in the Eastern Atlantic Ocean. Part 1: Method of measurement and near-surface distribution. Deep-Sea Research, Part I, 41, 659-675.

Hong S. and Elimelech M. (1997). Chemical and physical aspects of natural organic matter (NOM) fouling of nanofiltration membranes. Journal of Membrane Science, 132, 159-181.

Kimura K., Hane Y., Watanabe Y., Amy G. and Ohkuma N. (2004). Irreversible membrane fouling during ultrafiltration of surface water. Water Research, 38, 3431-3441.

Lee N., Amy G. and Croue J.-P. (2006). Low-pressure membrane (MF/UF) fouling associated with allochthonous versus autochthonous natural organic matter. Water Research, 40, 2357-2368.

Melbourne Water (2005). Salt shake up. In: The Source - A Magazine by Melbourne Water, Issue 34.

Mounier S., Patel N., Quilici L., Benaim J. Y. and Benamou C. (1999). Three-dimensional fluorescence of the dissolved organic carbon in the Amazon River. Water Research, 33, 15231533.

Nguyen M. L., Westerhoff P., Baker L., Hu Q. Esparza-Soto M. and Sommerfeld M. (2005). Characteristics and reactivity of algae-produced dissolved organic carbon. Journal of Environmental Engineering, 131, 1574 - 1582.

Nguyen, T., Fan, L., Roddick, F. A. and Harris, J. L. (2009). A comparative study of microfiltration and ultrafiltration of activated sludge-lagoon effluent. Desalination, 236, 208-215.

Schäfer A. I., Fane A. G., and Waite T. D. (2000). Fouling effects on rejection in the membrane filtration of natural waters. Desalination, 131, 215-224.

Sheng G. P. and Yu H. Q. (2006). Characterization of extracellular polymeric substances of aerobic and anaerobic sludge using three-dimensional excitation and emission matrix fluorescence spectroscopy. Water Research, 40, 1233-1239.

Shon H. K, Vigneswaran S., Kim In-S., Cho J., Ngo H. H. (2006). Fouling of ultrafiltration membrane by effluent organic matter: A detailed characterization using different organic fractions in wastewater. Journal of Membrane Science, 278, 232-238.

Soffer, Y., Adin, A. and Gilron, J. (2004). Threshold flux in fouling of membranes by colloidal iron. Desalination, 161, 207-221.

te Poele, S., Roorda, J. H. and van der Graaf, J. H. J. M. (2004). Influence of the size of membrane foulants on the filterability of WWTP-effluent. Water Science and Technology, 50(12), 111-118.

van den Broeke, Langergraber G. and Weiingartner A.(2006). On-line and in-situ UV/vis spectroscopy for multi-parameter measurements: a brief review. SpectroscopyEurope, 18(4), 1-4. 
Zularisam A. W., Ismail A. F. and Salim R. (2006). Behaviours of natural organic matters in membrane filtration for surface water treatment - A review. Desalination, 194, 211-231. 